Marquette University

e-Publications@Marquette

College of Education Faculty Research and

Publications

Education, College of

4-1-1999

\title{
Duty to Warn and Intervention with HIV-Positive Clients
}

Timothy Melchert

Marquette University, timothy.melchert@marquette.edu

Michele M. Patterson

Texas Tech University

Accepted version. Professional Psychology: Research and Practice, Vol 30, No. 2 (April1999): 180-186.

DOI. (C) 2019 American Psychological Association. Used with permission. 
Marquette University

e-Publications@Marquette

\section{Education Faculty Research and Publications/College of Education}

This paper is NOT THE PUBLISHED VERSION; but the author's final, peer-reviewed manuscript. The published version may be accessed by following the link in the citation below.

Professional Psychology : Research and Practice, Vol. 30, No. 2 (April 1999): 180-186. DOI. This article is (C) American Psychological Association and permission has been granted for this version to appear in ePublications@Marquette. American Psychological Association does not grant permission for this article to be further copied/distributed or hosted elsewhere without the express permission from American Psychological Association.

\section{Duty to warn and intervention with HIV- positive clients.}

Timothy P. Melchert

Marquette University, Milwaukee, WI, US

Michele M. Patterson

Texas Tech University, Lubbock, TX, US

\section{Abstract}

Complex ethical and legal issues are involved when an HIV-positive client presents a danger to others as a result of engaging in unprotected sex or needle sharing. This article presents a detailed assessment-and-intervention model that is based on the integration of ethical and legal principles with information about the level of risk associated with a client's behavior, the HIV status of the client, and the sexual or needle-sharing partner's awareness of the client's HIV status. Appropriate interventions, including the duty to warn, are identified for each of the risk levels.

\section{Introduction}

Complex clinical and legal issues arise for mental health professionals when their HIV-positive clients pose a potential danger to others as the result of engaging in needle sharing or unprotected sex (e.g., clients who became HIV-positive as a result of extramarital intercourse but continue to have sexual relations with their own 
spouse). If these clients are willing to warn their sexual or needle-sharing partners about their HIV status, these situations are often relatively easily resolved. If these clients are unwilling to warn the partners they put at risk, does the therapist have a Tarasoff-type duty to warn the third parties?

This ethical dilemma has been widely discussed over the past decade. Some have argued against making Tarasoff-type warnings in these cases (e.g., Melton, 1988), whereas others find that therapists do have a duty to warn, at least under particular circumstances (e.g., Harding, Gray, \& Neal, 1993). Many useful suggestions for handling these situations have also been offered (e.g., Knapp \& VandeCreek, 1990). However, a systematic outline regarding how to assess level of risk to others and determine appropriate interventions would be helpful in clinical practice. This article reviews the relevant ethical and legal considerations and provides a detailed model of assessment and intervention for HIV-positive clients who pose a risk for transmitting the virus to third parties.

\section{Ethical and Legal Considerations}

The ethical principle of beneficence underlies mental health professionals' duty to warn in Tarasoff-type situations. This principle obligates health care professionals to attempt to prevent harm to clients and third parties as long as doing so does not present the professional with significant risks or costs, and the benefits that clients or others would receive are not outweighed by the risks or costs incurred by the professional (Beauchamp \& Childress, 1994). In accordance with this principle, U.S. case law has found that physicians are obligated to protect third parties who are at risk for contracting contagious diseases from their patients (e.g., Skillings v. Allen, 1919; Wojcik v. Aluminum Company of America, 1959). For example, the case of Wojcik v.

Aluminum Company of America found the following:

It is the duty of a physician who is attending a patient afflicted with a contagious or infectious disease to exercise care in advising and warning members of the family and others who are liable to exposure of the existence and nature of the danger from the disease, to avoid doing any act which would tend to spread the infection, and to take all necessary precautionary measures to prevent its spread to other patients attended. A physician who fails to give such warning is negligent, and is liable in damages to any person injured as the direct and proximate result of his negligence. (pp. 355-356)

This principle was also applied to psychotherapists in the landmark case of Tarasoff $v$. Regents of California et al. (1976), which came to the following conclusion:

When a psychotherapist determines, or pursuant to the standards of his profession should determine, that his patient presents a serious danger of violence to another he incurs an obligation to use reasonable care to protect the intended victim against such danger; discharge of such duty may require the therapist to take one or more of various steps, depending on the nature of the case, including warning the intended victim or others likely to apprise the victim of the danger, notifying the police, or taking whatever steps are reasonably necessary under the circumstances. (p. 334)

Some have argued that the risk that HIV-positive clients pose to others is fundamentally different than the relatively straightforward risk posed in the Tarasoff case and that, consequently, HIV-positive clients' right to confidentiality outweighs the benefits of breaking their confidentiality to warn third parties of their possibility of contracting HIV (e.g., Girardi, Keese, Traver, \& Cooksey, 1988; Melton, 1988; Perry, 1989). The majority view on this issue, however, appears to support the opposite conclusion. For example, in 1988, the American Psychiatric Association Ad Hoc Committee on AIDS Policy developed guidelines to assist psychiatrists faced with potential duty-to-warn situations involving HIV-positive clients. With regard to confidentiality, they concluded the following: 
During the initial clinical evaluation ... if the physician has reason to suspect the patient is infected with HIV ... or is engaging in behavior that is known to transmit HIV disease, the physician should notify the patient of the specific limits of confidentiality. (American Psychiatric Association Ad Hoc Committee on AIDS Policy, 1988, p. 541)

When clients engage in behavior that puts third parties at risk for HIV infection, they made a further conclusion:

The physician should advise and work with the patient either to obtain the patient's agreement to terminate behavior that places other persons at risk of infection or to notify identifiable individuals who may be at continuing risk of exposure. If a patient refuses to agree to change his or her behavior or to notify the person(s) at risk or the physician has good reason to believe that the patient has failed to or is unable to comply with this agreement, it is ethically permissible for the physician to notify an identifiable person who the physician believes is in danger of contracting the virus. (American Psychiatric Association Ad Hoc Committee on AIDS Policy, 1988, p. 541)

Although this commission found that notifying a third party at risk was ethically permissible, the American Medical Association (AMA) Council on Ethical and Judicial Affairs (1988) took a stronger position in arguing that a physician who is aware that an HIV-positive patient is endangering a third party "should (1) attempt to persuade the infected patient to cease endangering the third party; (2) if persuasion fails, notify authorities; and (3) if the authorities take no action, notify the endangered third party" (p. 1361). In 1993, the American Psychiatric Commission on AIDS also suggested that psychiatrists actively urge clients practicing unsafe sexual behavior to get tested for HIV. Concerning informing past and current sexual or needle-sharing partners, the Commission found the following:

Psychiatrists should encourage HIV-infected patients to personally inform past contacts or have public health authorities do so. If the patient objects to informing contacts despite efforts to persuade the patient or if the patient is unable to do so (e.g., because of dementia), it is ethically permissible for the psychiatrist to contact public health authorities. (American Psychiatric Association Commission on AIDS, 1993, p. 852)

The American Psychological Association has not drafted a policy concerning the protection of third parties of clients with HIV. The following position, however, is maintained by the American Psychological Association:

1. A legal duty to protect third parties from HIV infection should not be imposed.

2. If, however, specific legislation is considered, then it should permit disclosure only when (a) the provider knows of an identifiable third party who the provider has compelling reason to believe is at significant risk for infection; (b) the provider has a reasonable belief that the third party has no reason to suspect that he or she is at risk; and (c) the client/patient has been urged to inform the third party and has either refused or is considered unreliable in his/her willingness to notify the third party.

3. If such legislation is adopted, it should include immunity from civil and criminal liability for providers who, in good faith, make decisions to disclose or not to disclose information about HIV infection to third parties. (American Psychological Association, 1991, p. 1)

Many states have enacted health and safety legislation concerning limits to confidentiality for persons with HIV. In 1987, AIDS was a reportable disease (i.e., AIDS could be reported to health departments) in all states, but only a few states required the reporting of persons who tested positive for HIV (Winston, 1987). By December 1996, however, 26 states required the confidential reporting by name of all persons who tested positive for HIV to a health department (Centers for Disease Control and Prevention, 1997). It appears now that all states allow any person to make good faith disclosures (normally in writing) regarding individuals' HIV status to a local, state, or federal department of health. It also appears that departments of health generally will notify individuals who 
the reporter believes were exposed to HIV or may be exposed in the near future. States also generally allow individuals to seek a court order to grant the reporting individual immunity from civil or criminal liability for disclosing HIV-related information to relevant third parties when HIV-infected persons will not authorize such disclosures themselves.

At the time of this writing, two thirds of the states had enacted legislation specifying limits to confidentiality regarding individuals' HIV status. Montana was the only state, however, that specifically protected mental health professionals from liability in making good faith disclosures to third parties at risk for HIV infection (Montana Health and Safety Code, 1997). In addition, all persons in Texas are given protection against liability for disclosing this information to the spouse of an HIV-positive individual (Texas Health and Safety Code, 1992). Several other states provide physicians protection against liability for making these disclosures, whereas mental health professionals are not specifically protected (California Health and Safety Codes, 1996; Connecticut Public Health and Well-Being Code, 1997; Georgia Evidence Code, 1994; Hawaii Health Codes, 1993; Illinois Health and Safety Codes, 1996; Indiana Health and Hospitals Codes, 1993; Louisiana Public Health and Safety Code, 1992; Maryland Health-General Code, 1994; New York Public Health Code, 1993; Pennsylvania Health and Safety Code, 1993; Rhode Island Health and Safety Code, 1996). Practitioners need to consult the codes currently pending in their states to be cognizant of the legal requirements and protections that apply to them.

Various ethical principles, court cases, and AMA and American Psychiatric Association policies suggest that psychotherapists may be morally obligated to warn third parties who are at risk for HIV infection. To date, no state requires that health care professionals make such warnings. On the other hand, very few states (two as of this article's publication) offer legal protection against any civil or criminal liability that psychotherapists might incur as a result of breaking client confidentiality to warn third parties about their risk for HIV infection. This lack of protection against liability (unless one gains a court order) may be viewed as the states' discouraging therapists from warning third parties at risk. Nevertheless, the moral obligation to warn third parties may be viewed as overriding this concern. Indeed, many states do not expressly permit or require therapists to break client confidentiality to warn the potential victims of homicidal clients, nor do they offer protection against potential liability arising from such warnings, and yet many therapists would judge nonetheless that they have a moral obligation to attempt to prevent such harm in these cases.

In coming years, legislatures and courts are likely to address more of the legal questions involved in warning third parties at risk for HIV infection as the need for answers to these questions becomes clearer. Psychotherapists may also want to communicate their concerns regarding these issues to professional organizations and state legislators so that adequate legal protections are enacted. When therapists feel a need to be protected against possible liability for making these types of warnings, however, they can generally seek such protection by petitioning a court to order that they be allowed to break a client's confidentiality to make a good faith warning to a third party at risk for contracting HIV from that client.

\section{Risk Level for HIV Transmission}

Apart from ethical and legal considerations, determining whether there is a duty to warn third parties at risk for HIV infection is also dependent on the level of risk to others associated with a client's behavior. When the risk for HIV transmission is sufficiently low, warning third parties about a client's HIV-positive status against the client's wishes is not justified. Determining the precise level of risk that an HIV-positive individual poses to others is complicated, however, because many factors contribute to the likelihood of HIV transmission. Among these factors are the amount and type of contact with sexual or needle-sharing partners, immunosuppression resulting from infection with other diseases in those partners, the presence of open lesions when sexual contact occurs, the genetic structure of the virus, and the viral load (or number of HIV) in the infected person (Kelly, 1995; Royce, Sena, Cates, \& Cohen, 1997; Seitz \& Mueller, 1994). As a result, determining the specific risk for transmitting HIV with regard to a particular contact between an infected and noninfected individual is generally 
not possible. General levels of risk can be identified, however, for three categories of behavior: casual contact, protected intercourse, and unprotected intercourse and needle sharing.

It is commonly known that HIV is not transmittable through casual contact, and there is no evidence of a single case of HIV being transmitted in this manner (Friedland et al., 1986; Kelly, 1995). HIV is carried in bodily fluids and cannot be transmitted through the air by sneezing, coughing, or by shaking hands with an infected individual. Even individuals who care for persons with AIDS are not at risk for contracting HIV, provided that they are not exposed to infected bodily fluids. Therefore, casual contact between HIV-positive clients and others represents no risk of HIV transmission and incurs no duty to warn under any circumstances.

"Safe sex" has been widely promoted to help protect individuals against HIV infection. Safe sexual practices include mutual masturbation and using condoms during intercourse. Masturbating an HIV-infected individual is not associated with any risk for HIV transmission unless one has open lesions on one's hands that could allow an exchange of bodily fluids. Engaging in protected intercourse, however, poses a slightly higher risk. Although it is clearly very effective for reducing the risk of HIV transmission, there is a significant failure rate associated with the use of condoms resulting from occasional condom breakage. The condom failure rate has not been investigated with regard to HIV transmission, but the failure rate among women relying on condoms for contraception is estimated at approximately 10 pregnancies per 100 women per year (Hatcher et al., 1986). The risk of condom breakage is also reduced through proper usage (e.g., ensuring proper lubrication and not using petroleum jelly, which weakens latex). Hearst and Hulley (1988) estimated that one instance of protected sexual intercourse with an HIV-positive partner is associated with a .0002 risk of contracting the virus, and 500 such encounters are associated with a .0909 risk of transmission. Therefore, practicing protected intercourse reduces the risk of contracting HIV from an infected individual to a negligible level, though it does not eliminate it altogether.

Unprotected intercourse with an HIV-positive individual is clearly associated with much more significant risks for contracting HIV, and receptive anal intercourse appears to be associated with the highest risk. In fact, among both same sex and opposite sex couples, unprotected anal intercourse is the best predictor of HIV transmission (Kelly, 1995). The probability of HIV transmission associated with unprotected receptive anal intercourse has been found to be between .008 to .032 (DeGruttola, Seage, Mayer, \& Horsburgh, 1989), whereas the probability for unprotected receptive vaginal intercourse is estimated at between .0005 and .0015 (Downs \& De Vincenzi, 1996). The probability for HIV transmission associated with insertive anal or vaginal intercourse and with oral intercourse appears to be lower than for the other forms of intercourse (Katz \& Gerberding, 1997).

The risk for HIV transmission when HIV-positive individuals share needles with other injection drug users is also relatively high. The probability of HIV infection associated with using contaminated needles is estimated at .0067 (Kaplan \& Heimer, 1992), and the dominant risk factor for contracting HIV in this manner is simply the frequency of needle sharing with HIV-positive individuals (Hughes \& Rutherford, 1995). The risk of this type of infection can be successfully eliminated, however, by (a) using new syringes each time a user injects, (b) using only one's own syringe and never borrowing or exchanging needles used by others, or (c) carefully cleaning used syringes (e.g., leaving full-strength bleach in a syringe for at least one minute, tapping the syringe to dislodge any dried blood fragments, discharging and again pulling up more bleach and leaving it for another minute, and then flushing with water; Kelly, 1995). Even when intervenous drug users engage in clean needle sharing, they must take care to avoid needle pricks, which also carry a potential for transmitting HIV (the estimated risk for HIV infection associated with contaminated needle pricks among health care workers is .0032; Gerberding, 1996).

It has become more socially acceptable since the beginning of the AIDS epidemic to ask sexual or needle-sharing partners about their HIV-status to protect oneself against contracting HIV. Individuals (as well as psychotherapists) must be aware of the possibility, however, that partners may not provide accurate information about their HIV status or their past high-risk behavior. Several studies have investigated this issue, 
and all have found that significant numbers of individuals report not disclosing their HIV status to their sexual partners. For example, Marks, Richardson, and Maldonado (1991) found that 45\% of a sample of HIV-positive men had been sexually active since learning of their HIV-positive status. Of these men, $52 \%$ had not disclosed their HIV-positive status to one or more of their sexual partners, and much of their sexual activity included unprotected anal, oral, or vaginal intercourse with partners believed to be HIV-negative. Wenger, Kusseling, Beck, and Shapiro (1994) inquired about the last sexual partner of a sample of HIV-positive patients and found that $9 \%$ reported having had unprotected intercourse with a partner believed to be HIV-negative, and an additional $13 \%$ had unprotected intercourse with a partner of unknown HIV status.

\section{Model of Risk Assessment and Intervention}

The following model of risk assessment and intervention regarding possible duty-to-warn situations with HIVpositive clients is similar to most models for dealing with dangerousness issues in that risk level forms the basis for determining the treatment interventions that should be considered (e.g., Monahan \& Steadman, 1996; Sommers-Flanagan \& Sommers-Flanagan, 1995). This approach was also used in past analyses regarding the duty to warn with HIV-positive clients (Knapp \& VandeCreek, 1990).

According to the present model, HIV-positive clients can be categorized into levels of no risk, negligible risk, and high risk with regard to the dangerousness of their behavior for HIV transmission. A fourth category includes those who represent a severe risk on the basis of an intent to harm others by infecting them with HIV. The first three categories are based on the research reviewed earlier, which found that casual contact involves no risk for HIV transmission, that safe sex and clean needle sharing involve only negligible risks for HIV transmission, and that unprotected intercourse and needle sharing present a significant risk for transmitting HIV. Several additional factors increase one's risk for transmitting HIV to others (e.g., engaging in higher risk behaviors such as receptive anal intercourse or needle sharing, the presence of sexually transmitted diseases during intercourse, higher frequency of the behavior, higher viral load; see previous discussion), and combining information about these factors will provide a more accurate assessment of transmission risk. Personality characteristics such as impulsivity or antisocial tendencies may also raise the risk that a person with HIV presents to others. Increased accuracy in the prediction of risk, however, is not necessary for implementing the proposed model in most situations.

HIV-positive clients can be placed into the above categories if reliable information regarding their HIV status and their behavior is known. In practice, however, there are many clients who could have contracted HIV as the result of having engaged in a large amount of high-risk behavior in the past but whose HIV status is unknown because they have not yet been tested for the virus. Therefore, the second factor in the model concerns whether clients have been tested for HIV and the results of any tests that they have received. Although the past behavior of some clients would clearly put them at risk for HIV infection, warning their partners is not justified without reasonably clear information that they present an actual (and not simply potential) risk to those partners as the result of being HIV-positive (the Texas Supreme Court recently upheld this principle in Santa Rosa v. Garcia, 1998). There have also been anecdotal reports of individuals who refused to be tested for HIV even though they had histories and symptoms that were consistent with AIDS. These clients obviously would present a potential danger to others if they were in fact HIV-positive and engaged in high-risk behavior, but again the duty to warn is not justified without reasonably clear information that a client is actually HIV-positive. To help deal with situations such as these, many states permit unconsented HIV testing if an individual is judged to be incompetent or a physician deems it medically necessary.

Information regarding a third factor is also required before it can be determined whether a duty to warn exists in these cases. A variety of court decisions have found that psychotherapists do not have a duty to warn third parties at risk from their clients if the third parties are already aware of the risks (Stromberg et al., 1988; note, however, that these authorities also concluded that "from a legal standpoint, a therapist would be well advised to warn even a person who has some awareness of the problem" [p. 538]). If individuals are not made aware of 
important risks associated with certain activities, their autonomy with regard to consensually participating in those activities is obviously impaired. When competent individuals understand the risks associated with various activities, however, their ability to consent to engaging in those activities is not necessarily impaired. Therefore, a duty to warn is not invoked if a therapist has sufficient reason to believe that the individuals who are engaging in high-risk behavior with an HIV-positive client are aware of the client's HIV status.

As the above analysis shows, information regarding these three factors (i.e., level of risk for HIV transmission associated with a client's behavior, results of any HIV testing, and partners' awareness of any test results) must be integrated to determine whether a duty to warn exists in these cases. When this is done, there are actually few situations in which such a duty is invoked (see Table 1). The clearest of these involves a client who indicates an intent to infect others with HIV. The potential victims may include sexual or needle-sharing partners but also any other individuals (e.g., persons stabbed with a blood-filled syringe). If this intent presents an imminent danger to others, even when the potential victims are not identifiable, the therapist must consider initiating an evaluation for involuntary hospitalization until the danger no longer exists. When the potential victims are identifiable, the therapist must also consider warning them in addition to notifying the police. These are the only situations in which a client's HIV status and his or her partners' awareness of that status are not necessarily relevant to determining the appropriate interventions to be undertaken. For example, even clients who are known to be HIV-negative but who intend to attack others with syringes may represent a danger that requires an involuntary psychiatric evaluation.

Table 1. Risk Levels, Duty to Warn, and Interventions Regarding HIV Transmission

\begin{tabular}{|c|c|c|c|c|c|c|}
\hline & & $\begin{array}{l}\text { HIV } \\
\text { testing }\end{array}$ & & & & \\
\hline $\begin{array}{l}\text { Level of risk } \\
\text { to others }\end{array}$ & $\begin{array}{l}\text { Engaging in } \\
\text { high risk } \\
\text { behavior }\end{array}$ & Tested & Results & $\begin{array}{l}\text { Partner(s) } \\
\text { aware of } \\
\text { test results }\end{array}$ & $\begin{array}{l}\text { Duty } \\
\text { to } \\
\text { warn }\end{array}$ & Interventions \\
\hline \multirow[t]{4}{*}{$\begin{array}{l}\text { None or very } \\
\text { low }\end{array}$} & $\mathrm{No}^{\mathrm{a}}$ & No & & & No & $\begin{array}{l}\text { 1. If client may have been } \\
\text { exposed to HIV in the past, } \\
\text { discus need for testing. } \\
\text { Educate about HIB as } \\
\text { appropriate. }\end{array}$ \\
\hline & $\mathrm{No}^{\mathrm{a}}$ & Yes & Negative & & No & $\begin{array}{l}\text { 2. If client may have been } \\
\text { exposed to HIV since one half } \\
\text { year before being tested, } \\
\text { discuss need for retesting. } \\
\text { Educate about HIV as } \\
\text { appropriate. }\end{array}$ \\
\hline & $\mathrm{No}^{\mathrm{a}}$ & Yes & Positive & & No & $\begin{array}{l}\text { 3. Encourage client to get } \\
\text { treatments and inform past } \\
\text { partners, health care providers, } \\
\text { etc., as appropriate. Provide } \\
\text { HIV-specific treatment } \\
\text { interventions. }\end{array}$ \\
\hline & Negligible $^{b}$ & No & & & No & $\begin{array}{l}\text { 4. If client may have been } \\
\text { exposed to HIV in the past, } \\
\text { discuss need for testing. } \\
\text { Support safe practices and } \\
\text { educate about HIV as } \\
\text { appropriate. }\end{array}$ \\
\hline
\end{tabular}




\begin{tabular}{|c|c|c|c|c|c|c|}
\hline & Negligible ${ }^{b}$ & Yes & Negative & Yes or no & No & $\begin{array}{l}\text { 5. If client may have been } \\
\text { exposed to HIV since one half } \\
\text { year before being tested, } \\
\text { discuss need for retesting. } \\
\text { Support safe practices and } \\
\text { educate about HIV as needed. }\end{array}$ \\
\hline \multirow[t]{2}{*}{ Low } & Negligible $^{b}$ & Yes & Positive & Yes & No & $\begin{array}{l}\text { 6. In addition to (3) above, } \\
\text { support safe practices. }\end{array}$ \\
\hline & Negligible $^{b}$ & Yes & Positive & No & No & $\begin{array}{l}\text { 7. In addition to (3) above, discuss } \\
\text { need for informing current } \\
\text { partner(s) of test results. } \\
\text { Support safe practices. }\end{array}$ \\
\hline \multirow[t]{2}{*}{ Intermediate } & $Y_{e s}^{c}$ & No & & & No & $\begin{array}{l}\text { 8. Encourage client to cease high- } \\
\text { risk behaviors and get HIV } \\
\text { testing. Educate about HIV as } \\
\text { needed. }\end{array}$ \\
\hline & Yes $^{c}$ & Yes & Negative & Yes or no & No & $\begin{array}{l}\text { 9. If client has engaged in high- } \\
\text { risk behavior since being tested } \\
\text { with anyone not known to be } \\
\text { HIV-negative, encourage client } \\
\text { to cease high-risk behaviors } \\
\text { and get HIV retesting. Educate } \\
\text { about HIV as needed. }\end{array}$ \\
\hline \multirow[t]{2}{*}{ High risk } & $Y_{e s}^{c}$ & Yes & Positive & Yes & No & $\begin{array}{l}\text { 10. In addition to ( } 3 \text { ) above, discuss } \\
\text { need to cease high-risk } \\
\text { behaviors and educate about } \\
\text { HIV as needed. }\end{array}$ \\
\hline & Yes $^{c}$ & Yes & Positive & No & Yes & $\begin{array}{l}\text { 11. Strongly encourage client to } \\
\text { cease high-risk behavior. } \\
\text { Encourage client to inform } \\
\text { partner(s). If client will not } \\
\text { cease behaviors or inform } \\
\text { partner(s), therapist or } \\
\text { authorities should notify the } \\
\text { partner(s). See also (3) above. }\end{array}$ \\
\hline Severe risk & $\begin{array}{l}\text { Intent to } \\
\text { infect }\end{array}$ & $\begin{array}{l}\text { Yes or } \\
\text { no }\end{array}$ & & & Yes & $\begin{array}{l}\text { 12. Assess dangerousness to } \\
\text { others and need for } \\
\text { hospitalization and informing } \\
\text { police and potential victims. }\end{array}$ \\
\hline
\end{tabular}

${ }^{a}$ Persons not engaging in high-risk behaviors refers to those who are not engaging in sexual intercourse, intraveneous drug use, or other activities that carry a significant risk of exchanging bodily fluids with another individual.

${ }^{\mathrm{b}}$ Negligible-risk behaviors refer to safe sex and clean needle-sharing.

${ }^{\mathrm{c}}$ High-risk behaviors refer to unprotected intercourse and unclean needle-sharing.

The second instance in which a duty to warn may exist is when a client known to be HIV-positive engages in high-risk behavior with a partner who is unaware of the client's HIV status. As a result of being unaware of this information, the partner cannot make an autonomous decision regarding engaging in behaviors that put him- or herself at risk for contracting HIV. In such cases, we recommend following the American Psychiatric Association policies discussed earlier. Therapists should first attempt to obtain the client's agreement to cease the high-risk 
behavior or to notify his or her partner(s) of their risk for HIV infection. If the client will not agree to either of these alternatives, the therapist should consider various steps such as directly warning the partners, requesting that a health department warn the partners, or notifying the police. It is also relevant in these cases that more than half of the states have made it a crime to knowingly expose another individual to HIV (see David, 1995).

When clients decide to inform their partners of their HIV-positive status, it is generally preferable that the psychotherapist be present, whether the contacts are made over the telephone or through in-person meetings (Knapp \& VandeCreek, 1990). This scenario provides the therapist with assurance that the appropriate information is communicated and allows an opportunity to provide clients' partners with any additional information or support that they may need. If a client agrees to inform his or her partner(s) but does not want the therapist present, the client should be given general medical information about HIV and HIV testing to give to his or her partner(s). If a client refuses to inform his or her partner(s) about his or her HIV status after a reasonable period of providing encouragement or if there is sufficient reason to believe that the client was unreliable in informing his or her partner(s), the various AMA, American Psychiatric Association, and APA policies discussed earlier suggest that it is ethically permissible for therapists to inform the client that the partner(s) will be contacted against his or her wishes and provided with appropriate information. Therapists should maintain client confidentiality and anonymity when making these contacts and release only information that is germane for the purpose (e.g., notifying someone only that they may have been exposed to HIV and providing information about HIV testing; Stanard \& Hazler, 1995). Therapists usually can also rely on public health departments that will notify both the present and past partners of individuals with HIV.

A variety of other interventions should also be considered even when a duty to warn third parties is not identified. Clients obviously can dramatically reduce their risk for contracting HIV if they completely avoid the sexual and drug use behavior that puts them at risk. This should be encouraged for all clients for whom it is relevant, but it is particularly important for those at the intermediate level of risk to others (see Table 1). The "morning after pill" treatment, a combination of AIDS medications taken immediately after exposure to HIV, may be effective in preventing infection, so clients who have just been exposed to HIV should quickly be given referrals for an evaluation for this treatment (postexposure prophylactic treatment for health care workers and rape victims is recommended to begin within hours after exposure but no later than $72 \mathrm{hr}$ after exposure; Katz \& Gerberding, 1997). There is also a substantial amount of research demonstrating the efficacy of psychoeducational and psychotherapeutic interventions designed to reduce individuals' risk for HIV infection (e.g., Carey et al., 1997; Kalichman, Kelly, Morgan, \& Rompa, 1997), and a variety of therapy models have been developed for HIV-positive individuals (e.g., Winiarski, 1997). When clients' past behavior puts them at risk for having contracted HIV but they have not yet been tested, they should be encouraged to get tested so that if they are HIV-positive they can receive potentially helpful treatments, notify past partners who may have been infected, and take precautions to prevent exposing others to infection. HIV tests detect the presence of antibodies for the virus, however, and people do not develop measurable levels of HIV antibodies for 2-6 months after infection (Powell, 1996). Therefore, clients should get tested or retested if they may have been exposed to HIV within the past 6 months (there have been rare cases where measurable levels of antibodies were not produced for up to 1 year or longer; Andrews \& Novick, 1995).

Clients with HIV who are not currently engaging in high-risk behaviors should also consider notifying past sexual or needle-sharing partners if those past partners are unaware that they have been exposed to the virus. Clients' past dangerous behavior does not incur upon therapists a duty to warn if that behavior is not part of a continuing pattern that is predictive of likely imminent behavior; that is, the duty to warn is invoked only when clients represent a danger to third parties in the reasonably near future (Monahan \& Steadman, 1996; Stromberg et al., 1988). Nevertheless, therapists should discuss with HIV-positive clients the need for past partners to be notified so that those individuals can get tested and take steps to prevent transmission to others as well as receive any needed medical treatments if they are HIV-positive. When embarrassment or fear 
prevents a client with HIV from personally notifying his or her past partner(s), the client can usually rely on health departments for making these notifications.

It is important for therapists to keep current with major research advances regarding HIV and AIDS because these advances affect the interventions that will be helpful to HIV-positive clients and their sexual and needlesharing partners (a particularly useful resource for this purpose is Kalichman, 1998). The recent advances involving protease inhibitor medications and the "morning after pill" do not represent a cure for HIV infectionin fact, between $15 \%$ and $35 \%$ of the participants in protease inhibitor clinical trials have not experienced clinical benefits, and the failure rate appears to be even higher for patients treated in normal health care settings (Kalichman, Ramachandran, \& Ostrow, 1998). Therefore, until a successful vaccine or cure is developed, the guidelines presented here are likely to remain applicable. Therapists also need to stay current with state laws and court decisions that regulate the kinds of disclosures that are permitted or required and that may or may not be protected against criminal or civil liability. Mental health and family law regarding limits to confidentiality for adolescents is also relevant in some cases. Information regarding local resources that may be helpful to clients and their partners (e.g., health department services, HIV testing facilities, HIV test kits sold over-thecounter, clean needle and drug treatment programs) is also needed for carrying out appropriate interventions. It is important that therapists document their assessments and interventions as well as consult with respected colleagues regarding difficult cases (Monahan, 1993). Agencies should also consider developing policies and guidelines around this issue and ensure that staff are properly trained. In addition, therapists may want to include a provision in their informed consent statements concerning limits to confidentiality for clients who are HIV-positive. This provision might simply state that therapists may be required to inform the partners of HIVpositive clients if clients engage in high-risk sexual behavior or unclean needle sharing and do not inform their partners themselves.

Dealing with dangerousness to other issues tends to be particularly stressful for practitioners. These cases also must be handled competently in order to limit one's exposure to malpractice liability and complaints lodged against one's license. Psychotherapists who handle these cases appropriately, however, also give themselves the opportunity to prevent significant harm. This represents the most important benefit of being well prepared to make appropriate interventions in cases that include risks to third parties for HIV infection.

\section{References}

American Medical Association Council on Ethical and Judicial Affairs. (1988). Ethical issues involved in the growing AIDS crisis. Journal of the American Medical Association, 259, 1360-1361.

American Psychiatric Association Ad Hoc Committee on AIDS Policy. (1988). AIDS policy: Confidentiality and disclosure. American Journal of Psychiatry, 145, 541.

American Psychiatric Association Commission on AIDS. (1993). AIDS policy: Position statement on confidentiality, disclosure, and protection of others. American Journal of Psychiatry, 150, 852.

American Psychological Association. (1991). Legal liability related to confidentiality and the prevention of HIV transmission. Washington, DC: APA Council of Representatives.

Andrews, L. J., \& Novick, L. B. (1995). HIV care: A comprehensive handbook for California Health and Safety Codes, . 41E Ann. Cal. Codes $\S 121015$ (1996).

Beauchamp, T. L., \& Childress, J. F. (1994). Principles of biomedical ethics (4th ed.). New York: Oxford University Press.

California Health and Safety Codes, . 41E Ann. Cal. Codes § 121015 (1996).

Carey, M. P., Maisto, S. A., Kalichman, S. C., Forsyth, A. D., Wright, E. M., \& Johnson, B. T. (1997). Enhancing motivation to reduce the risk of HIV infection for economically disadvantaged urban women. Journal of Consulting and Clinical Psychology, 65, 531-541.

Centers for Disease Control and Prevention. (1997). HIV/AIDS surveillance report, 9. (1), Atlanta, GA: Author. Connecticut Public Health and Well-Being Code,. 19A Conn. Gen. Stat. Ann. § 19a-584 (1997). 
David, L. A. (1995). The legal ramifications in criminal law of knowingly transmitting AIDS. Law and Psychology Review, 19, 259-271.

DeGruttola, V., Seage, G. R., III, Mayer, K. H., \& Horsburgh, C. R., Jr. (1989). Infectiousness of HIV between male homosexual partners. Journal of Clinical Epidemiology, 42, 849-856.

Downs, A. M., \& De Vincenzi, I. (1996). Probability of heterosexual transmission of HIV: Relationship to the number of unprotected sexual contacts. Journal of Acquired Immune Deficiency Syndrome Human Retrovirology, 11, 388-395.

Friedland, G. H., Saltzman, B. R., Rogers, M. F., Kahl, P. A., Lesser, M. L., Mayers, M. M., \& Klein, R. S. (1986). Lack of transmission of HTLV-III/LAV infection to household contacts of patients with AIDS or AIDS-related complex with oral candidiasis. The New England Journal of Medicine, 314, 344-349.

Georgia Evidence Code,. 13A Geo. Code Ann. § 38-723 (1994).

Gerberding, J. L. (1996). Prophylaxis for occupational exposure to HIV. Annals of Internal Medicine, 125, 497501.

Girardi, J., Keese, R., Traver, L. B., \& Cooksey, D. (1988). Psychotherapist responsibility in notifying individuals at risk for exposure to HIV. The Journal of Sex Research, 25, 1-27.

Harding, A. K., Gray, L. A., \& Neal, M. (1993). Confidentiality limits with clients who have HIV: A review of ethical and legal guidelines and professional policies. Journal of Counseling and Development, 71, 297-305.

Hatcher, R. A., Guest, F., Stewart, F., Stewart, G. K., Trussell, J., Cerel, S., \& Cates, W. (1986). Contraceptive Technology 1986-1987 (13th rev. ed.). New York: Irvington.

Hawaii Health Codes, 6 Haw. Rev. Stat. § 325-101 (1993).

Hearst, N., \& Hulley, S. B. (1988). Preventing the heterosexual spread of AIDS: Are we giving our patients the best advice?Journal of the American Medical Association, 259, 2428-2431.

Hughes, M. J., \& Rutherford, G. W. (1995). The epidemiology of HIV/AIDS. Seminars in Dermatology, 14, 191201.

Illinois Health and Safety Codes, 27 III. Comp. Stat. Ann. § 305/9 (1996).

Indiana Health and Hospitals Codes, 16 Ind. Stat. Ann. § 16-41-7-3 (1993).

Kalichman, S. C. (1998). Understanding AIDS: A guide for mental health professionals (2nd ed.). Washington, DC: American Psychological Association.

Kalichman, S. C., Kelly, J. A., Morgan, M., \& Rompa, D. (1997). Fatalism, current life satisfaction, and risk for HIV infection among gay and bisexual men. Journal of Consulting and Clinical Psychology, 65, 542-546.

Kalichman, S. C., Ramachandran, B., \& Ostrow, D. (1998). Protease inhibitors and the new AIDS combination therapies: Implications for psychological services. Professional Psychology: Research and Practice, 29, 349-356.

Kaplan, E. J., \& Heimer, R. (1992). A model-based estimate of HIV infectivity via needle sharing. Journal of Acquired Immune Deficiency Syndrome, 5, 1116-1118.

Katz, M. H., \& Gerberding, J. L. (1997). Postexposure treatment of people exposed to the human immunodeficiency virus through sexual contact or injection-drug use. The New England Journal of Medicine, 336, 1097-1100.

Kelly, J. A. (1995). Changing HIV risk behavior: Practical strategies. New York: Guilford Press.

Knapp, S., \& VandeCreek, L. (1990). Application of the duty to protect to HIV-positive patients. Professional Psychology: Research and Practice, 21, 161-166.

Louisiana Public Health and Safety Code, . 22C La. Stat. Ann. § 1300.13 (1992).

Marks, G., Richardson, J. L., \& Maldonado, N. (1991). Self-disclosure of HIV infection to sexual partners. American Journal of Public Health, 81, 1321-1323.

Maryland Health-General Code,. Md. Code Ann. § 18-337 (1994).

Melton, G. B. (1988). Ethical and legal issues in AIDS-related practice. American Psychologist, 43, 941-947.

Monahan, J. (1993). Limiting therapist exposure to Tarasoff liability: Guidelines for risk containment. American Psychologist, 48, 242-250.

Monahan, J., \& Steadman, H. J. (1996). Violent storms and violent people: How meteorology can inform risk communication in mental health law. American Psychologist, 51, 931-938. 
Montana Health and Safety Code, 8 Mont. Code Ann. § 50-16-1003 (1997).

New York Public Health Code, 44 N.Y. Law. § 2782 (1993).

Pennsylvania Health and Safety Code,. 35 Pa. Stat. Ann. § 7609 (1993).

Perry, S. (1989). Warning third parties at risk for AIDS: Policy is a barrier to treatment. Hospital and Community Psychiatry, 40, 158-161.

Powell, J. (1996). AIDS and HIV-related diseases: An educational guide for professionals and the public. New York: Plenum.

Rhode Island Health and Safety Code, 4B R.I. Gen. Laws § 23-6-17 (1996).

Royce, R. A., Sena, A., Cates, W., Jr., \& Cohen, M. S. (1997). Sexual transmission of HIV. The New England Journal of Medicine, 336, 1072-1078.

Santa Rosa v. Garcia,. 964 S.W.2d 940 (Tex. Sup. Ct. (1998).

Seitz, S. T., \& Mueller, G. E. (1994). Viral load and sexual risk: Epidemiologic and policy implications of HIV/AIDS. In E. H.Kaplan \& M. L.Brandeau (Eds.), Modeling the AIDS epidemic: Planning, policy, and predictionNew York: Raven Press.

Skillings v. Allen, . (1919). 173 N.W. 663

Sommers-Flanagan, J., \& Sommers-Flanagan, R. (1995). Intake interviewing with suicidal patients: A systematic approach. Professional Psychology: Research and Practice, 26, 41-47.

Stanard, R., \& Hazler, R. (1995). Legal and ethical implications of HIV and duty to warn for counselors: Does Tarasoff apply? Journal of Counseling and Development, 73, 397-400.

Stromberg, C. D., Haggarty, D. J., Leibenluft, R. F., McMillian, M. H., Mishkin, B., Rubin, B. L., \& Trilling, H. R. (1988). The psychologist's legal handbook. Washington, DC: Council for the National Register of Health Service Providers in Psychology.

Tarasoff v. Regents of the University of California et al.,. 551 P.2d 334 (1976).

Texas Health and Safety Code, 1 Tex. Code Ann. § 81.103 (1992).

Wenger, N. S., Kusseling, F. S., Beck, K., \& Shapiro, M. F. (1994). Sexual behavior of individuals infected with the human immunodeficiency virus. Archives of Internal Medicine, 154, 1849-1854.

Winiarski, M. G. (Ed.). (1997). HIV mental health for the 21st century. New York: New York University Press. Winston, M. (1987). AIDS and a duty to protect: Commentary. The Hastings Center Report, 17, 22-23.

Wojcik v. Aluminum Co. of America,. 183 N.Y.S.2d 351 (1959). 